\title{
CAN SOCIAL MEDIA CAMPAIGNS BACKFIRE? EXPLORING CONSUMERS' ATTITUDES AND WORD-OF-MOUTH TOWARDS FOUR SOCIAL MEDIA CAMPAIGNS AND ITS IMPLICATIONS ON CONSUMER-CAMPAIGN IDENTIFICATION
}

\begin{abstract}
In response to the unprecedented growth of social media, companies are continuously creating unique social media campaigns encouraging customers to share their advertising messages. However, many of these social campaigns end up backfiring. The purpose of this study is to examine consumers' preferences towards four social media campaigns and to investigate the impact of positive and negative word-of-mouth and social value on consumercampaign identification. Using a sample of 525 respondents in Australia, the results show social media campaigns that contain negative messages are more likely to receive negative word-of-mouth while partnering with non-profit organisations may help generate positive word-of-mouth. This study will assist marketing managers to better understand the consumers' perceptions on recent social media campaigns in Australia.
\end{abstract}

Keywords: social media campaign, social media, word of mouth 


\section{Introduction}

In response to unprecedented growth of social media, companies have launched unique social media campaigns encouraging customers to share their advertising messages (Shen and Bissel 2013). However, many of these social campaigns end up backfiring. For example, Starbucks launched the \#racetogether campaign to start a conversation about the race between its employees and customers. However, this campaign ended up backfiring by producing widespread ridicule on social media and prompting Starbucks senior vice president of communication to delete his Twitter account (BBC 2015; Washington Times 2015). Similarly, Woolworths, one of the largest grocery stores in Australia, launched a social media campaign superimposing its logo over images of Australian and New Zealand Army Corp (ANZAC) soldiers with the slogan "Fresh in our Memory”. The public outcry suggested that the campaign also backfired and people accused the company of trivializing the ANZAC memory (Sydney Morning Herald 2015). Negative responses nation-wide quickly appeared on Facebook and various other social media channels, branding the company as 'grotesque' and 'revolting' (ABC 2015). This negative response significantly diminished the success of the campaign and forced the advertisers to shut it down. Most likely, this resulted in negative financial implications for Woolworths, but, even more importantly, it affected the company’s reputation (Dhar and Chang 2009)

The true challenge stems from the observation that negative word-of-mouth (WOM) can spread at an incredible pace and the long-build brand trust can severely weaken within as short as 24 hours (Hoffman and Fodor 2010). Word-of-mouth can be defined as "oral person to person communication between a receiver and a communicator whom the receiver perceives as non-commercial, regarding a brand, a product or a service” Arndt (1967, p. 3). The previous examples show the challenges in developing a successful social media campaign the public views positively and shares with others (Naylor et al. 2012; Podnar and Javernik 
2012). Thus, the first research objective is to understand and rank consumers' attitudes towards four social media campaigns and the companies launching the campaigns. We will consider the factors of positive and negative WOM, social value, and consumer-company identification. The second research objective is to investigate the impact of positive and negative WOM as well as perceived social value on customer-company (CC) identification. The study will make several theoretical contributions related to social identity theory and consumers' WOM. The findings will shed the light on the social reasons of why consumers relate closely to brands and companies in the context of social media promotions. Moreover, the results of this study will assists marketing managers understand consumers' perceptions on four social media campaigns, whether they identify with the companies, and whether they are likely to provide negative or positive WOM.

\section{Literature Review}

This section will discuss the importance of social media, the underlying theoretical framework informing this study, followed by a discussion of positive and negative WOM, CC identification and social value.

\section{Social media}

Over the past decades, social media platforms have become an integral aspect of everyday life, altering the way the population communicates with businesses, colleagues, families, and friends (Adamapoulos and Todri 2015; Gensler, 2013; Ularu 2014; Smith, Fitscher, and Yongjian 2012). We can illustrate the rapid global expansion of social media through a comparison. It took radio 38 years and TV 13 years to reach 50 million listeners while it took Facebook's social networking site only four years to reach more than 500 
million users globally (Walaski 2013). By the first quarter of 2015, Facebook had 1.44 billion monthly active users (Statista 2015).

Social media provides an easily accessible platform, in which one can keep in touch with friends and family, share content with others, collaborate with colleagues, meet new people, and becomes a source of information (Kietzmann et al. 2011; Scheepers et al. 2014). Social media platforms have been widely adopted by the Australian population (Cowling 2015) and Facebook is the most used social media platform in the country with over nine million Australian users accessing the service each day (Ross 2014).

A recent study surveyed Facebook users and identified seven unique uses and gratifications people gained from using the social media site: social connection, shared identities, content, social investigation, social network surfing, and status updates (Joinson 2008). Nielsen’s Global Trust in Advertising report (2013) states that $84 \%$ of global consumers trust recommendations from friends and family (earned media) above all other forms of advertising. This number is up by $6 \%$ since 2007. In addition, online reviews have become an important source for information consumers increasingly trust. Sixty eight percent of global consumers indicated they trust messages on this platform, which marks an increase of $6 \%$ in four years. Ads on social networks are trusted by $48 \%$ of the global population with no statistical comparison available from 2007 (Nielsen, 2013). These findings align with previous research profiling the importance of WOM communication (Godes and Myzlin, 2004; Hennig-Thurau et al. 2015), which is a key information source in the consumer decision-making process (Solomon et al. 2013). Hence, it has become extremely important for companies to get people to like and share their social media content with their respective friends.

Marketing managers are still learning to operate and grasp the 'Wild Wild West' of the social media landscape and its potential for direct communication and engagement with 
their target audience members (Hoffman and Fodor 2010). It is therefore crucial to understand how the population perceives social media campaigns and learn what it takes to engage with customers successfully through the diverse social media channels (Kietzmann et al. 2011).

\section{Theoretical framework - Social identity theory}

Social identity refers to an individuals' sense of who they are based on their group membership (Tajfel 1972; Tajfel and Turner 1979). The theory has been used to explain reason and motivation why consumers relate closely to brands and companies (Du et al. 2007; Marin and Ruiz 2007; Perez 2009) and thus has become the theoretical basis for research into consumers’ identification (Perez 2009). Social identity theorists argue people tend to classify themselves and others into different social categories according to such traits as gender, religion, ethnicity, hobbies, or sports teams, for example. This allows them to be a member with the group with which they identify (Tajfel and Turner 1979). Tajfel and Turner (1979) proposed three mental processes in evaluating others as 'in-group' and 'out-group' or, in other words, "us versus them". The first process is categorization. People tend to categorize objects to understand and identify with them and they do the same with the social group. The second process is social identification; people adopt the identity of the selected group and perceive themselves to be a member of that group. The third process is social comparison, when they start comparing themselves with other groups.

We suggest that these three mental processes also apply in the context of social media. People categorise, identify, and compare various social media messages and they evaluate how a brand or company portrays themselves in the social media space. People strive to achieve or maintain a positive social identity, boosting their self-esteem through favourable comparisons they can make within the group (Abram and Hogg 1988; Brown 2000; 
McKinley et al. 2014). Social media allows people to portray themselves as how they want to be perceived by others, thereby achieving higher levels of self-esteem. Consequently, social identity theory becomes an important framework to understand the process of consumer identification with social media.

Positive and negative word-of-mouth

Word-of-mouth communication is one of the most important factors influencing sales growth (Moore 1995; Sweeney et al. 2014) and it is particularly important in the social media space where positive and negative WOM can have an effect on purchase intentions (Gunawan and Huarng, in press). Consumers engage in WOM for many reasons such as satisfaction, loyalty, quality, and perceived value (Adamapoulos and Todri 2015; Alexandrov et al. 2013; de Matos and Rossi 2008). Emotion elicited by the WOM message affects its sharing in an online context (Berger and Miklman 2012; Berger and Schwartz 2011; Dobele et al. 2007). This emotional reaction will then influence how consumers identify with the company, which then will either produce positive or negative WOM. Based on the previous discussion, this study proposes one directional conceptual framework (see Figure 1).

\section{Insert Figure 1 About Here}

\section{Consumer-campaign identification}

The concept consumer-campaign identification was adapted from the concept customer-company identification (Ashforth and Mael 1989). Customer-company identification refers to a cognitive state related to consumer closeness and connection to a company or brand (Dutton et al. 1994). Bhattacharya and Sen (2003) suggest that some of the strongest CC identification relationships rest on how consumers identify themselves with the company and how they perceive the connection between employees and their companies 
(Ashforth and Mael 1989; Dutton et al. 1994). When a consumer identifies with an organization, the consumer will develop a sense of connectedness to that organization (Mael and Ashforth 1992). Nonetheless, studies show that that consumers do not need to interact or feel strong interpersonal relationship to perceive themselves as members of a group (Bhattacharya and Sen 2003; Brewer 1991). In the context of online advertising, particularly on social media networks, consumers will form an active evaluation towards the ads and then decide to ignore or connect with the ads through liking or sharing them on the social media platform (Tsand et al. 2014). Laroche et al. (1996) found that a consumer's attitude toward a specific brand is affected by his/her familiarity with the brand. Hence, consumers' identification with the campaigns will influence their subsequent behaviour.

Previous research has found that a 'like' through social media affirms consumers' identity (Youyou et al. 2015). 'Likes’ can predict several identification traits of the users. Therefore, the content of a social media campaign represents the consumer's identification with the campaign. The benefits of investigating CC identification in a social media context are important for marketing managers and researchers to understand better the effects of their promotion efforts. Social media advertising can produce both positive and negative effects on consumers' perception toward the company or brand. The aim for companies is to produce positive effects to improve loyalty and mediate negative press coverage (Ahearne et al. 2015; Arli, Rundle-Thiele and Lasmono 2015).

\section{Social value}

Perceived value is one of the primary customer motivations for buying or using a certain product or service (Sweeney and Soutar 2001). A review of the literature indicated four components of perceived value: the functional or utilitarian (i.e., perception of utility associated with the use); the emotional or hedonic (i.e., mood associated with the use); the 
monetary or value-for-money (i.e., utility compared to the cost usage involved); and, the social (i.e., self-perception of social status associated with the use). In the context of social media, social value is a widely used component (Cocosila and Igonor 2015; Yen 2013). Sweeney and Soutar (2001) described social value as the utility derived from the product's ability to enhance social concept. From this perspective, when consumers decide to share a hashtag or social media campaign, they are trying to enhance their online acceptance and approval among their peers.

In summary, this research has two research objectives. First, it aims to identify consumers' attitudes on four social media campaigns and the respective companies that launched them. It further investigates positive and negative WOM intentions, as well as social value and consumer-company identification. Second, the study will investigate the impact of positive and negative WOM as well as perceived social value on CC identification.

\section{Methodology}

\section{Data collection}

Using paper-based survey, we collected the sample from undergraduate students at a large public university in Australia. The sample also included their friends, colleagues, members of their immediate families. We also used intercept surveys. Students received credit points for participating in this study. Of the 600 distributed paper questionnaires, participants returned 576. Incomplete surveys with too many missing values were removed from the sample. Of these, 525 were usable, yielding a response rate of $86 \%$. Male and female respondents were almost equal in number, $52 \%$ and $48 \%$, respectively. Most participants were between 18-20 years (24\%) and 21-29 years old (43\%). The highest percentage of respondents earned under $\$ 20,000$ (32\%) followed by $\$ 21,000-\$ 40,000$ (23\%). The majority 
of respondents were single (60\%), followed by married respondents (27\%). Table 1 summarizes the demographic profile of this study.

Insert Table 1 About Here

\section{Questionnaire design}

The survey featured four different social media campaigns. These campaigns were selected to represent four different types of content (i.e. positive - playful, positive partnership with non-for-profit, neutral, and negative). These campaigns are recent real world social media campaigns launched by four different companies. Campaign 1 was X-Box congratulating Sony Play Station for launching their new console: "Congratulations on your launch, Sony”. Campaign 2 was Honda partnering with the Paediatric Brain health foundation to raise funds to support their research with \#cheerance. Campaign 3 was launched by Qantas airlines asking people to share their ideal flying experience: “What is your dream luxury inflight experience? (Be Creative!) Answer must include \#QantasLuxury”. Finally, Campaign 4 was Microsoft mocking Google for the data breach of their customers: “Keep calm while we steal your data - Google”.

First, we asked participants for their attitudes toward these campaigns overall, their attitude towards the company launching the campaign, and their attitudes toward the other company partnered with or they targeted. In addition, we asked respondents whether they identified closely with the campaign and what their perceived social value would be from sharing this campaign. Finally, we asked respondents whether they would share positive or negative WOM toward each of the four campaigns. We exposed survey participants to each of the social media campaigns before answering the questions in the paper-based survey. 


\section{Measures}

We derived attitude toward the campaign from an average of subjects' ratings on three five-point scales adapted from Mackenzie and Lutz (1989): bad/good, unpleasant/pleasant, and unfavourable/favourable. We measured the social value using a five-point Likert scale with four items developed by Sweeney and Soutar (2001) (e.g. 'would make a good impression on other people' -- 1=very likely; 5=very unlikely). We measured campaign identification through the one-item scale used by Sen et al. (2006), complemented with three specific items aimed to reflect the degree of perceived similarity (Bhattacharya and Sen 2003; Marín and Ruiz 2007). We measured positive and negative WOM propensity using three items scales developed by Gabriela (2013). An example of the scale item would be 'to what extent do you think people would recommend this company to their online networking peers' for positive WOM (1=very likely; 5=very unlikely) and 'to what extend to you think people will share negative talk about this company’ WOM (1=very likely; 5=very unlikely). Analysis (see Table 2 for the scale items and the Cronbach alpha scores). The

To address the first objective, we used a general linear model with repeated measures to investigate and rank differences between consumers' attitudes toward the four social media campaigns, their attitudes towards the companies, positive WOM, social value, and CC identification. To address the second objective, we used multiple regressions to test the impact of positive and negative WOM as well as social value on CC identification as a dependent variable.

Insert Table 2 About Here

\section{Results}

Consumer attitudes towards the social media campaigns - Table 3 shows Honda (Campaign 2) $(\mathrm{M}=3.77)$ had the most positive attitudes of consumers followed by Qantas 
(Campaign 3) (M=3.67), X-Box (Campaign 1) (M=3.21) and Microsoft (Campaign 4)

$(M=2.74)$. Campaign 4 is significantly different from Campaigns 1, 2, and 3. Campaign 1 is significantly different from Campaigns 1, 2, and 4. Results indicate that partnering with a not-for-profit organisation (Campaign 2) may result in more positive attitudes towards the organisation running the campaign. In addition, results show consumers do not positively perceive badmouthing (Campaign 4) or mocking a competitor (Campaign 1).

Consumer attitudes towards the company - For this index, we observed similarities to the previous featured attitudinal preferences. Table 4 illustrates that Qantas (company 3) ( $M=3.85)$ received the most positive attitude scores followed by Honda (company 2) (M=3.65), X-Box (company 1) $(M=3.25)$ and Microsoft (4) $(M=3.25)$. Significant differences exist between companies 3 and 1, 2, and 4. Similarly, significant differences exist between company 2 and company 1, 3, and 4 .

Word-of-mouth (positive) - Qantas (Campaign 3) (M=2.29) is most likely to receive positive WOM, followed by Honda (Campaign 2) (M=2.58), Microsoft (Campaign 4) ( $\mathrm{M=2.59)}$ and $\mathrm{X}$-Box (Campaign 1) $(\mathrm{M}=2.63)$. Campaign 3 is significantly different from Campaigns 1, 2, and 4 (see Table 5). Asking consumers to share their personal experiences may invoke positive WOM. Similarly, partnering with not-for-profit organisations may also generate positive WOM.

Word-of-mouth (negative) - Table 6 illustrates that Microsoft (Campaign 4) (M=2.50) is most likely to receive negative WOM followed by X-Box (Campaign 1) (M=2.91), Qantas (Campaign 3) (M=3.01) and Honda (Campaign 2) (M=3.46). There are significant differences between Campaign 4 and Campaign 1, 2, and 3. Moreover, Campaign 2 is significantly different to Campaign 1, 3 and 4 . These findings match the expected outcome after presenting the positive WOM results. Interestingly, attacking the competitor through 
social media may backfire with the company that launches the campaign, as the findings of the study indicated.

Social value - Table 7 indicates that, Honda (Campaign 2) $(\mathrm{M}=3.18)$ had the highest social value, followed by Qantas (Campaign 3) (M=3.40), Microsoft (Campaign 4) (M=3.57), and X-Box (Campaign 1) (M=3.76). Campaign 2 is significantly different from Campaigns 1, 3, and 4. No significant difference existed between Campaigns 1 and 4. Lower mean values indicated that consumers who share this message are more likely to feel accepted by their peers and perceive themselves to be making a good impression on other people by sharing these campaigns. The results indicate that partnering with not-for-profit organisations (Campaign 2) may result in a benefit to the company. The partnership may insulate the company from negative comments.

Consumer-campaign identification (CC identification) - Table 8 shows that Honda (Campaign 2) (M=3.14) had the highest CC identification followed by Qantas (Campaign 3) ( $M=3.06), X-B o x ~(C a m p a i g n ~ 1) ~(M=3.01)$, and Microsoft (Campaign 4) (M=2.76). These findings align with our previous findings, suggesting that attacking or mocking a competitor is likely to backfire. A significant difference existed between Campaign 4 and Campaigns 1 , 2, and 3. The results show that consumers tend to identify less with a negative social media campaign.

Insert Table 3-8 About Here

Does WOM and social value influence CC identification?

Table 9 shows that positive WOM significantly influences CC identification for all four social media campaigns. The more positive WOM the campaign generates, the more likely consumers are to identify with the company. Moreover, negative WOM significantly predicts all campaigns except for X-Box (Campaign 1). The more negative WOM the 
campaign generates, the less likely the consumer will identify with the company. Microsoft (Campaign 4) mocked their competitor for the data breach concerning their customers and received the highest negative WOM score. We found that consumers are more likely to convey a negative WOM on this social media campaign. These findings indicate that, particularly in the context of comparative advertising, such efforts appear to fail to take off if the combative company cannot live up to the standards of its attack.

Furthermore, social value significantly influences CC identification on all campaigns. The more the campaign was able to improve consumers' feeling of social value, the more they will identify with the company. This supports previous research suggesting social value is an important factor when sharing social media content within a social network (Adamapoulos and Todri 2015).

\section{Insert Table 9 About Here}

Finally, the standardized beta scores show social value is a stronger predictor of CC identification than negative and positive WOM. We can infer that using content and messaging focusing on social approval is a better strategy to attract and connect with customers than trying to launch comparative social media campaigns. Moreover, we were surprised to find that negative WOM is stronger than positive WOM for all campaigns except $\mathrm{X}$-Box. Thus, companies should avoid launching negative framed campaigns, as it is more likely to weaken its relationship with its customers.

\section{Discussion and Managerial Implication}

This study made several theoretical contributions. Social identity theory highlights that people with similar character traits (e.g. religion, ethnicity, hobbies) tend to relate more closely with people that view the world in a similar way (Tajfel and Turner 1979). 
1979) to explain why consumers either relate or dissociate from brands, advertising messages and companies. As individuals strive to maintain positive social identity they are less likely to share (WOM) and engage with companies that deviate from one’s social identity. Our findings confirmed this as negatively perceived social media campaigns forced consumers to disassociate with the company and discouraged their willingness to share their message - or in the worst case share and comment negatively on the advertising of the company. In contrast, it was found that positive social media campaigns are more likely to be accepted and shared (WOM) by consumers as it provides them with the opportunity to share an organisation's message that aligns with their core values and beliefs and therefore allows them to portray themselves positively to the group which they identify with. WOM communication is directly linked to purchase intentions (Gunawan and Huarng, in press) and sales (Sweeney et al. 2014) and achieving positive WOM is therefore particularly important on social media platforms, where $84 \%$ of consumers trust recommendations from friends and family (Nielsen, 2013). With previous research indicating that negative reviews/comments are more impactful than positive ones (Chevalier et al. 2006; Trusov et al. 2011) companies have to be very mindful of negative WOM. Humorous ads are more likely to resonate with audiences than reality or fear (Nielsen 2013) and our findings support that customers were more likely to share positive rather than negative content. For example, Microsoft's campaign resembled strong criticism towards a competitor and consumers did not identify with this messaging strategy. Similarly, while X-Box’s campaign aimed to be humorous, it relayed a potentially sarcastic message subtly reminding consumers about the long delay in manufacturing Sony’s previous game console. Consequently, consumers perceived the campaign to be negative rather than humours. In summary, our findings align with previous research profiling the importance of WOM communication (Godes and Myzlin, 2004; Hennig-Thurau et al. 2015) and it is recommended that companies refrain from content that may be perceived negatively when 
aiming to motivate and encourage consumers to spread and share their offerings. Our practical implications are addressed hereafter.

Moreover, the results of this study made several practical contributions: first, partnering with not-for-profit organisations to promote a worthy cause may be an effective strategy to increase positive perception towards the company. In turn, consumers are more likely to share and post more positive comments on social media. However, companies need to find a good fit between their core businesses and their not-for-profit partners. Studies found that found that fit dimensions significantly influenced consumers response toward the campaigns and companies need to communicate the fit to consumers (Nand and Heo 2007; Zdravkovic et al. 2010). Second, ‘mocking' or criticising the competition may backfire on the companies who launch the campaign, particularly if the 'aggressor' is not to be perceived as producing a better product or having higher ethical standards. We found in our study sample that consumers disliked this strategy. Consequently, they are less likely to share social media campaigns, which will significantly influence the success of the campaign. Finally, the results reveal that consumers identify less with the negative content of social media campaigns. One of the reasons for this lack of identification is consumers' attitudes toward advertising in general tend to be negative (Tsang et al. 2004). Creating negative content will exacerbate consumers' perceptions of the image of the company. Brand managers working in the social media area should move away from negative or insensitive messages. Brand managers working in the social media space should move away from negative or insensitive messages. Preventing a social media campaign from backfiring may be achieved through cross-departmental editorial checks and experiments. Involving several staff members within the company as well as testing campaign elements with the target audience may help to reduce unexpected negative outcomes. 
We found that social value has a stronger impact on CC identification compared to negative and positive WOM. The more positive the campaign and the more the campaign increases consumers' social value perceptions, the more consumers will identify themselves with the company. Consequently, positive and cooperative messages have more potential to increase the effectiveness of a campaign and to cultivate CC identification. However, negative WOM is a stronger predictor than positive WOM. Thus, companies need to focus more on how to reduce negative WOM than how to generate more positive WOM. When consumers are able to identify more with the company, they are more likely to be loyal and willing to protect the company from negative media coverage (Ahearne, 2005).

\section{Limitations and Future Research}

The results of this study should be interpreted in light of its limitations. The findings in this survey derived from responses by undergraduate students at a large public university in Australia, their friends, colleagues, and members of their immediate families. While the paper-based survey methodology allowed for effective way data collection, survey responses reflect self-reported behaviour, rather than actual metered data. As well, we have to be judicious with using instruments that only measure proxy behaviours such as intention to give WOM. Numerous studies revealed significant gaps between consumers’ attitudes their subsequent behaviour (Lee and Holden 1999; Kilbourne and Beckmann 2002; Fraj and Martinez 2007; Moisander 2007). In addition, this study did not pre-test the content of the campaigns. Future research may use experiment methods and investigate the impact of the various social media campaigns how word-of-mouth. Finally, this study did not ask consumers’ brand familiarity which might influence consumers’ responses toward these campaigns. Future research should examine correlation between consumer brand familiarity 
and the subsequent effect on consumers' responses toward their social media campaigns and their willingness to share these. 


\section{References}

ABC (2015). Woolworths takes down Anzac 'Fresh in our Memories' website after social media backlash'. Accessible at http://www.abc.net.au/news/2015-04-14/woolworthsunder-fire-for-anzac-promotion/6392848 (last accessed April 19, 2015).

Abrams, Dominic, and Michael A. Hogg (1988), "Comments on the motivational status of self-esteem in social identity and intergroup discrimination." European Journal of Social Psychology, 18,4, 317-334.

Adamopoulos, Panagiotis, and Vilma Todri (2014), Social Media Analytics: The Effectiveness of Promotional Events on Brand User Base in Social Media. Accessible at http://aisel.aisnet.org/icis2014/proceedings/SocialMedia/8/. (last accessed 20 August 2015).

Ahearne, Michael, Chitrabhan B. Bhattacharya, and Thomas Gruen (2005), "Antecedents and consequences of customer-company identification: expanding the role of relationship marketing," Journal of applied psychology, 90,3 ,574-590.

Alexandrov, Aliosha, Bryan Lilly, and Emin Babakus (2013), "The effects of social-and selfmotives on the intentions to share positive and negative word of mouth, "Journal of the Academy of Marketing Science 41,5, 531-546.

Andrei, Andreia Gabriela (2013), "A Word-Of-Mouse Approach For Word-Of-Mouth Measurement," The USV Annals of Economics and Public Administration, 12(2), 87-93.

Arli, Denni, Sharyn Rundle-Thiele, and Hari Lasmono (2015), "Consumers' evaluation toward tobacco companies: implications for social marketing," Marketing Intelligence and Planning, 33,3, 276-291.

Arndt, Johan (1967), Word of mouth advertising: A review of the literature, Advertising Research Foundation.

Ashforth, Blake E., Spencer H. Harrison, and Kevin G. Corley (2008), "Identification in organizations: An examination of four fundamental questions," Journal of management, 34, 3, 325-374.

BBC (2015), Starbucks \#RaceTogether campaign mocked online. Accessible at: http://www.bbc.com/news/blogs-trending-31932351 (last accessed: April 21, 2015).

Berger, Jonah, and Katherine L. Milkman (2012), "What makes online content viral?, "Journal of marketing research, 49,2, 192-205.

and Eric M. Schwartz (2011), "What drives immediate and ongoing word of mouth?," Journal of Marketing Research, 48,5, 869-880.

Bhattacharya, Chitrabhan B., and Sankar Sen (2003), "Consumer-company identification: A framework for understanding consumers' relationships with companies, " Journal of marketing, 67,2, 76-88. 
Brewer, Marilynn B. (1991), "The social self: On being the same and different at the same time," Personality and social psychology bulletin 17, 5, 475-482.

Brown, Rupert (2000), "Social identity theory: Past achievements, current problems and future challenges," European Journal of Social Psychology, 30, 6, 745-778.

Buffardi, Laura E., and W. Keith Campbell (2008), "Narcissism and social networking web sites." Personality and social psychology bulletin, 34,10, 1303-1314.

Chevalier, J., \& Mayzlin, D. (2006). The Effect of Word of Mouth on Sales: Online Book Reviews. Journal of Marketing Research, 43(3), 345-354. doi: 10.1509/jmkr.43.3.345

Cocosila, Mihail, and Andy Igonor (2015), "How important is the 'social'in social networking? A perceived value empirical investigation," Information Technology and People, 28,2, 110.

Cowling, David. (2015), Social Media Statistics Australia. Accessible at http://www.socialmedianews.com.au/social-media-statistics-australia-february-2015/ (last accessed April 20, 2015).

De Matos, Celso Augusto, and Carlos Alberto Vargas Rossi (2008), "Word-of-mouth communications in marketing: a meta-analytic review of the antecedents and moderators," Journal of the Academy of Marketing Science, 36,4,578-596.

Dickinson, Sonia, and Alison Barker (2007), "Evaluations of branding alliances between nonprofit and commercial brand partners: the transfer of affect, "International Journal of Nonprofit and Voluntary Sector Marketing, 12,1, 75-89.

Dhar, Vasant, and Elaine A. Chang (2009), "Does chatter matter? The impact of usergenerated content on music sales," Journal of Interactive Marketing, 23, 4, 300-307.

Dobele, Angela, Adam Lindgreen, Michael Beverland, Joëlle Vanhamme, and Robert Van Wijk (2007), "Why pass on viral messages? Because they connect emotionally, " Business Horizons, 50, 4, 291-304.

Du, Shuili, C. B. Bhattacharya, and Sankar Sen (2007), "Reaping relational rewards from corporate social responsibility: The role of competitive positioning," International journal of research in marketing, 24, 3, 224-241.

Dutton, Jane E., Janet M. Dukerich, and Celia V. Harquail (1994), "Organizational images and member identification," Administrative science quarterly, 39, 2, 239-263.

Fraj, Elena, and Eva Martinez (2007), "Ecological consumer behaviour: an empirical analysis," International Journal of Consumer Studies, 31, 1, 26-33.

Gensler, Sonja, Franziska Völckner, Yuping Liu-Thompkins, and Caroline Wiertz (2013). "Managing brands in the social media environment," Journal of Interactive Marketing 27, no. 4 (2013): 242-256. 
Godes, David, and Dina Mayzlin (2004), "Using online conversations to study word-of-mouth communication, " Marketing science, 23, 4, 545-560.

Gunawan, Dedy Darsono, and Kun-Huang Huarng (2015), "Viral effects of social network and media on consumers' purchase intention," Journal of Business Research, doi:10.1016/j.jbusres.2015.06.004

Hennig-Thurau, Thorsten, Caroline Wiertz, and Fabian Feldhaus (2014), "Does Twitter matter? The impact of microblogging word of mouth on consumers' adoption of new movies," Journal of the Academy of Marketing Science, 43,3, 375-394.

Hoffman, Donna L., and Marek Fodor (2010), "Can you measure the ROI of your social media marketing," MIT Sloan Management Review, 52, 1, 41-49.

Joinson, Adam N. (2008), "Looking at, looking up or keeping up with people?: motives and use of facebook." Proceedings of the SIGCHI conference on Human Factors in Computing Systems. ACM, 2008.

Kietzmann, Jan H., Kristopher Hermkens, Ian P. McCarthy, and Bruno S. Silvestre (2011),"Social media? Get serious! Understanding the functional building blocks of social media," Business horizons, 54, 3, 241-251.

Kilbourne, William E., Suzanne C. Beckmann, and Eva Thelen (2002), "The role of the dominant social paradigm in environmental attitudes: A multinational examination," Journal of business Research, 55, 3, 193-204.

Lee, Julie Anne, and Stephen JS Holden (1999), "Understanding the determinants of environmentally conscious behaviour," Psychology and Marketing, 16, 5, 373-392.

Luarn, P., Huang, P., Chiu, Y. P., and Chen, I. J. (2015). Motivations to engage in word-ofmouth behavior on social network sites. Information Development, 0266666915596804.

MacKenzie, Scott B., and Richard J. Lutz (1989), "An empirical examination of the structural antecedents of attitude toward the ad in an advertising pretesting context," The Journal of Marketing, 53,2, 48-65.

Mael, Fred, and Blake E. Ashforth (1992), "Alumni and their alma mater: A partial test of the reformulated model of organizational identification," Journal of organizational Behavior, 13, 2, 103-123.

Moisander, Johanna (2007), "Motivational complexity of green consumerism," International journal of consumer studies, 31, 4, 404-409.

Nan, X., \& Heo, K. (2007), “Consumer responses to corporate social responsibility (CSR) initiatives: Examining the role of brand-cause fit in cause-related marketing," Journal of Advertising, 36,2, 63-74.

Naylor, Rebecca Walker, Cait Poynor Lamberton, and Patricia M. West (2010) "Beyond the "like" button: the impact of mere virtual presence on brand evaluations and purchase intentions in social media settings." Journal of Marketing, 76, 6, 105-120. 
Nielsen (2013). Global Trust in Advertising Report.

Podnar, Klement, and Pina Javernik (2012), "The effect of word of mouth on consumers' attitudes toward products and their purchase probability, " Journal of Promotion Management 18, 2, 145-168.

Rifon, Nora J., Sejung Marina Choi, Carrie S. Trimble, and Hairong Li (2004),"Congruence effects in sponsorship: The mediating role of sponsor credibility and consumer attributions of sponsor motive," Journal of Advertising, 33, 1, 30-42.

Ross, Monique (2014), Facebook turns 10: The social network in numbers. Accessible at: http://www.abc.net.au/news/2014-02-04/facebook-turns-10-the-social-network-innumbers/5237128 (last accessed 25 April 2015).

Scheepers, Helana, Rens Scheepers, Rosemary Stockdale, and Nurdin Nurdin (2014), "The dependent variable in social media use," Journal of Computer Information Systems, 54, 2, 2534.

Sen, Sankar, Chitra Bhanu Bhattacharya, and Daniel Korschun (2006), "The role of corporate social responsibility in strengthening multiple stakeholder relationships: A field experiment." Journal of the Academy of Marketing science 34, 2, 158-166.

Shen, Bin, and Kimberly Bissell. (2013), "Social media, social me: A content analysis of beauty companies' use of facebook in marketing and branding, "Journal of Promotion Management 19,5, 629-651.

Slater, Michael D. (2007), "Reinforcing spirals: The mutual influence of media selectivity and media effects and their impact on individual behavior and social identity," Communication Theory, 17, 3, 281-303.

Smith, Andrew N., Eileen Fischer, and Chen Yongjian (2012), "How does brand-related usergenerated content differ across YouTube, Facebook, and Twitter?," Journal of Interactive Marketing, 26, 2, 102-113.

Solomon, Michael R., Darren William Dahl, Katherine White, Judith L. Zaichkowsky, and Rosemary Polegato (2014), “ Consumer behavior: buying, having, and being, "Upper Saddle River, NJ: Prentice Hall.

Statista (2015). Facebook: number of monthly active users worldwide 2008-2015. Accessible at: http://www.statista.com/statistics/264810/number-of-monthly-active-facebook-usersworldwide/ (last accessed: April 27, 2015).

Stern, Barbara (1994), “A revised model for advertising: multiple dimensions of the source, the message, and the recipient, “ Journal of Advertising, 23(2), 5-16.

Sydney Morning Herald (2015). Woolworths debacle: Minister for Veterans Affairs attacksAnzac ad campaign. Accessible at: http://www.smh.com.au/federal-politics/politicalnews/woolworths-debacle-minister-for-veterans-affairs-attacks-anzac-ad-campaign20150415-1ml8fk.html (last accessed April 21, 2015). 
Sweeney, Jillian, and Geoffrey N. Soutar (2001), "Consumer perceived value: The development of a multiple item scale." Journal of retailing 77, 2, 203-220.

, Geoff Soutar, and Tim Mazzarol (2014), "Factors enhancing word-of-mouth influence: positive and negative service-related messages," European Journal of Marketing 48, 1/2, 336-359.

Tajfel, Henri (1972), "Social categorization (English manuscript of La categorisation sociale) In: Moscovici S, editor," Introduction a la psychologie sociale. Paris: Larousse, 30-37. , and John C. Turner (1979), "An integrative theory of intergroup conflict, "The social psychology of intergroup relations, 33, 47, 74.

Trimble, Carrie and Nora J. Rifon. "Consumer perceptions of compatibility in cause-related marketing messages, " International Journal of Nonprofit and Voluntary Sector Marketing 11, 1, 29-40.

Trusov, M., Bucklin, R., \& Pauwels, K. (2009). Effects of Word-of-Mouth Versus Traditional Marketing: Findings from an Internet Social Networking Site. Journal of Marketing, 73(5), 90-102. doi: 10.1509/jmkg.73.5.90

Tsang, Melody, Shu-Chun Ho, and Ting-Peng Liang (2004), "Consumer attitudes toward mobile advertising: An empirical study," International Journal of Electronic Commerce, 8, 3 , 65-78.

Walaski, Pamela (2013), "Social Media: Powerful Tools for SHandE Professionals, "Professional Safety, 58, 04, 40-49.

Ularu, Vera (2014), "Gender Differences in Online Media Usage," Journal of Research in Gender Studies, 1, 961-966.

Washington Times (2015), Starbucks 'Race Together' campaign backfires: Communications VP deletes Twitter account. Accessible at http://www.washingtontimes.com/news/2015/mar/17/starbucks-communications-vp-deletestwitter-accoun/?page=all (last accessed June 20, 2015).

Youyou, Wu, Michal Kosinski, and David Stillwell (2015), "Computer-based personality judgments are more accurate than those made by humans," Proceedings of the National Academy of Sciences, 112, 4, 1036-1040.

Zdravkovic, S., Magnusson, P., \& Stanley, S. M. (2010), “Dimensions of fit between a brand and a social cause and their influence on attitudes," International Journal of Research in Marketing, 27(2), 151-160 


\section{Appendix}

Figure 1. Conceptual Framework

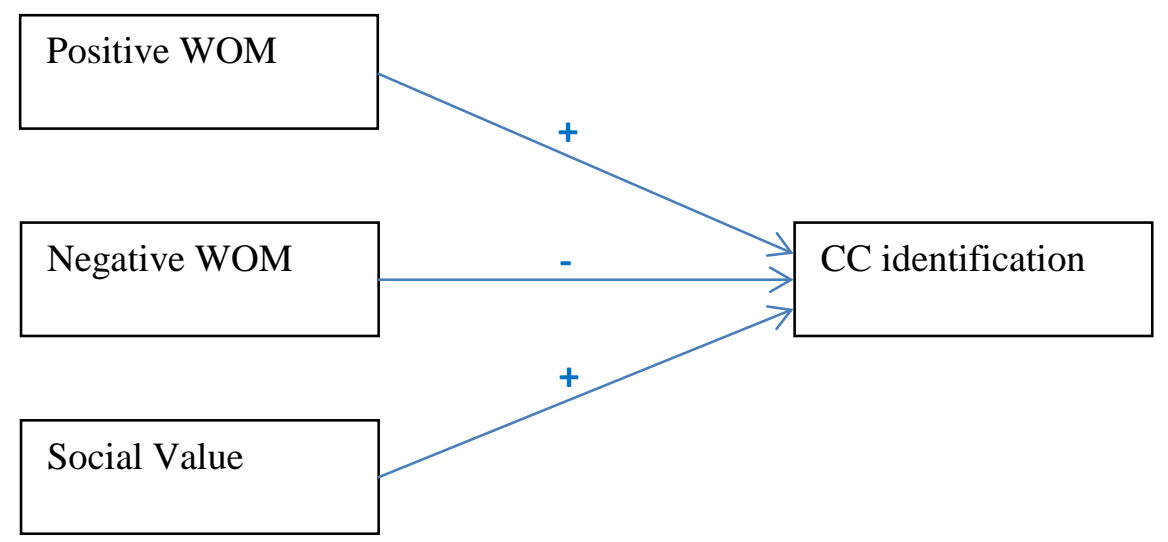


Table 1. Demographic profile (N=521)

\begin{tabular}{|c|c|c|}
\hline Demographic & Frequency & Percentage \\
\hline \multicolumn{3}{|l|}{ Gender } \\
\hline Male & 267 & $52 \%$ \\
\hline Female & 251 & $48 \%$ \\
\hline \multicolumn{3}{|l|}{ Age } \\
\hline $18-20$ years old & 126 & $24 \%$ \\
\hline 21-29 years old & 224 & $43 \%$ \\
\hline 30-39 years old & 54 & $10 \%$ \\
\hline 40-49 years old & 39 & $8 \%$ \\
\hline 50 and above & 75 & $15 \%$ \\
\hline \multicolumn{3}{|l|}{ Income } \\
\hline below $\$ 20,000$ & 163 & $32 \%$ \\
\hline$\$ 21,000-\$ 40,000$ & 117 & $23 \%$ \\
\hline$\$ 41,000-\$ 60,000$ & 83 & $17 \%$ \\
\hline$\$ 61,000-\$ 80,000$ & 66 & $13 \%$ \\
\hline$\$ 80,000-\$ 100,000$ & 29 & $6 \%$ \\
\hline$\$ 101,000$ and above & 46 & $9 \%$ \\
\hline \multicolumn{3}{|l|}{ Marital Status } \\
\hline Single & 305 & $60 \%$ \\
\hline Married & 140 & $27 \%$ \\
\hline Divorced & 13 & $3 \%$ \\
\hline Widowed & 8 & $2 \%$ \\
\hline Others & 43 & $8 \%$ \\
\hline \multicolumn{3}{|l|}{ Time spent on social media } \\
\hline 10 minutes or less & 123 & $24 \%$ \\
\hline 10-30 minutes & 84 & $17 \%$ \\
\hline 31-60 minutes & 90 & $18 \%$ \\
\hline $1-2$ hours & 93 & $18 \%$ \\
\hline $2-3$ hours & 60 & $12 \%$ \\
\hline $3+$ hours & 56 & $11 \%$ \\
\hline
\end{tabular}


Table 2. Scale items

\begin{tabular}{|c|c|c|c|c|c|}
\hline \multirow[t]{2}{*}{ Items } & \multicolumn{4}{|c|}{ Cronbach $\alpha$} & \multirow[t]{2}{*}{ Source } \\
\hline & Campaign 1 & Campaign 2 & Campaign 3 & Campaign 4 & \\
\hline Attitude toward the campaign & .93 & .58 & .93. & .84 & Mackenzie and Lutz, 1989 \\
\hline \multicolumn{6}{|l|}{ Bad-good } \\
\hline \multicolumn{6}{|l|}{ Unpleasant-pleasant } \\
\hline \multicolumn{6}{|l|}{ Unfavourable-favourable } \\
\hline Social value & .83 & .92 & .74 & .66 & Sweeney and Soutar, 2001 \\
\hline \multicolumn{6}{|l|}{$\begin{array}{r}\text { Sharing this message would help me to feel acceptable by } \\
\text { others }\end{array}$} \\
\hline \multicolumn{6}{|l|}{ Sharing this message would improve the way I am perceived } \\
\hline \multicolumn{6}{|l|}{$\begin{array}{r}\text { Sharing this message would make a good impression on other } \\
\text { people }\end{array}$} \\
\hline \multicolumn{6}{|l|}{ Sharing this message would give its owner social approval } \\
\hline Campaign identification & .62 & .88 & .66 & .84 & $\begin{array}{l}\text { Sen et al., 2006; Bhattacharya and } \\
\text { Sen 2003; Marín and Ruiz } 2007\end{array}$ \\
\hline \multicolumn{6}{|l|}{ The way I am fits in with what I perceive of this campaign } \\
\hline \multicolumn{6}{|l|}{ I am similar to what I think this campaign represents } \\
\hline \multicolumn{6}{|l|}{ I am similar to how I perceive this campaign } \\
\hline \multicolumn{6}{|l|}{$\begin{array}{r}\text { The image I have of this campaign overlaps with my self- } \\
\text { image }\end{array}$} \\
\hline Positive Word of Mouth & .70 & .77 & .88 & .89 & Gabriela, 2013 \\
\hline \multicolumn{6}{|l|}{$\begin{array}{l}\text { To what extent do you think people would recommend 'this } \\
\text { company' to their online networking peers? }\end{array}$} \\
\hline \multicolumn{6}{|l|}{$\begin{array}{l}\text { To what extent do you think people will 'SHARE to friends' } \\
\text { events and offers posted online by 'this company? }\end{array}$} \\
\hline \multicolumn{6}{|l|}{$\begin{array}{r}\text { To what extent do you think 'this company' would receive } \\
\text { 'LIKE' from online users? }\end{array}$} \\
\hline Negative Word of Mouth & .79 & .77 & .87 & .72 & Gabriela, 2013 \\
\hline \multicolumn{6}{|l|}{$\begin{array}{r}\text { To what extent do you think 'this company' would receive } \\
\text { negative comments from Internet users? }\end{array}$} \\
\hline \multicolumn{6}{|l|}{$\begin{array}{r}\text { To what extent do you think people will 'SHARE' negative } \\
\text { talk about 'this company? }\end{array}$} \\
\hline $\begin{array}{r}\text { To what extent do you think people would 'LIKE' negative } \\
\text { comments about 'this company? }\end{array}$ & & & & & \\
\hline
\end{tabular}


Table 3. Attitude toward the campaign

\begin{tabular}{|l|l|l|l|}
\hline Campaign & Mean (Ranking) & S.D & Note \\
\hline Campaign 2 & $3.77(1)$ & 1.39 & Campaign 2 is sig different than campaign 1,4 \\
\hline Campaign 3 & $3.67(2)$ & 0.91 & Campaign 3 is sig different than campaign 1,4 \\
\hline Campaign 1 & $3.21(3)$ & 0.99 & Campaign 1 is sig different than campaign 2,3,4 \\
\hline Campaign 4 & $2.74(4)$ & 1.26 & Campaign 4 is sig different than campaign 1,2,3 \\
\hline
\end{tabular}

Note: $1=$ bad; $5=$ good

Table 4. Attitude toward the company

\begin{tabular}{|l|l|l|l|}
\hline Campaign & Mean (Ranking) & S.D & Note \\
\hline Campaign 3 & $3.85(1)$ & 1.10 & Company 3 is sig different than campaign 1,2,4 \\
\hline Campaign 2 & $3.65(2)$ & 0.94 & Company 2 is sig different than campaign 1,3,4 \\
\hline Campaign 1 & $3.25(3 / 4)$ & 1.25 & Company 1 is sig different than campaign 2,3 \\
\hline Campaign 4 & $3.25(3 / 4)$ & 1.17 & Company 4 is sig different than campaign 2,3 \\
\hline
\end{tabular}

Note: $1=$ negative; $5=$ =positive

Table 5. Positive WOM

\begin{tabular}{|l|l|l|l|}
\hline Campaign & Mean (Ranking) & S.D & Note \\
\hline Campaign 3 & $2.29(1)$ & 0.84 & Campaign 3 is sig different than campaign 1,2,4 \\
\hline Campaign 2 & $2.58(2)$ & 0.86 & Campaign 2 is sig different than campaign 3 \\
\hline Campaign 4 & $2.59(3)$ & 0.95 & Campaign 4 is sig different than campaign 3 \\
\hline Campaign 1 & $2.63(4)$ & 0.93 & Campaign 1 is sig different than campaign 3 \\
\hline
\end{tabular}

Note: $1=$ very likely; $5=$ =ery unlikely

Table 6. Negative WOM

\begin{tabular}{|l|l|l|l|}
\hline Campaign & Mean (Ranking) & S.D & Note \\
\hline Campaign 4 & $2.50(1)$ & 0.04 & Campaign 4 is sig different than campaign 1,2,3 \\
\hline Campaign 1 & $2.91(2)$ & 0.10 & Campaign 1 is sig different than campaign 2,4 \\
\hline Campaign 3 & $3.01(3)$ & 0.04 & Campaign 3 is sig different than campaign 2,4 \\
\hline Campaign 2 & $3.46(4)$ & 0.08 & Campaign 2 is sig different than campaign 1,3,4 \\
\hline
\end{tabular}

Note: $1=$ very likely; $5=$ =ery unlikely

Table 7. Social Value

\begin{tabular}{|l|l|l|l|}
\hline Campaign & Mean (Ranking) & S.D & Note \\
\hline Campaign 2 & $3.18(1)$ & 0.94 & Campaign 2 is sig different than campaign 1,3,4 \\
\hline Campaign 3 & $3.40(2)$ & 1.08 & Campaign 3 is sig different than campaign 1,2,4 \\
\hline Campaign 4 & $3.57(3)$ & 1.05 & Campaign 4 is sig different than campaign 2,3 \\
\hline Campaign 1 & $3.76(4)$ & 2.23 & Campaign 1 is sig different than campaign 2,3 \\
\hline
\end{tabular}

Note: 1 =very likely; $5=$ =very unlikely

Table 8. Consumer-Campaign Identification

\begin{tabular}{|l|l|l|l|}
\hline Campaign & Mean (Ranking) & S.D & Note \\
\hline Campaign 2 & $3.14(1)$ & 1.91 & Campaign 2 is sig different than campaign 4 \\
\hline Campaign 3 & $3.06(2)$ & 0.78 & Campaign 3 is sig different than campaign 4 \\
\hline Campaign 1 & $3.01(3)$ & 0.92 & Campaign 4 is sig different than campaign 4 \\
\hline Campaign 4 & $2.76(4)$ & 1.03 & Campaign 1 is sig different than campaign 1,2,3 \\
\hline
\end{tabular}

Note: $1=$ strongly Agree; $5=$ strongly disagree 
Table 9. Regression Results

\begin{tabular}{|c|c|c|c|c|}
\hline & Campaign 1 & Standardized beta & t-value & Sig \\
\hline \multirow[t]{8}{*}{$\mathrm{a}$} & Dependent variable: CC identification & & & \\
\hline & Constant & & 21.178 & 0.000 \\
\hline & Positive WOM & 0.132 & 2.959 & 0.004 \\
\hline & Negative WOM & -0.077 & -1.774 & 0.077 \\
\hline & Social Value & 0.092 & 4.983 & 0.000 \\
\hline & $\mathrm{R}^{2}=0.037$ & F-value $=6.484$ & & \\
\hline & Adjusted $\mathrm{R}^{2}=\mathbf{0 . 0 3 1}$ & Sig $=\mathbf{0 . 0 0 0}$ & & \\
\hline & Campaign 2 & Standardized beta & t-value & Sig \\
\hline \multirow[t]{8}{*}{$\mathrm{a}$} & Dependent variable: $\mathbf{C C}$ identification & & & \\
\hline & Constant & & 14.427 & 0.000 \\
\hline & Positive WOM & 0.099 & 2.294 & 0.022 \\
\hline & Negative WOM & -0.139 & -3.379 & 0.001 \\
\hline & Social Value & 0.288 & 6.720 & 0.000 \\
\hline & $\mathrm{R}^{2}=0.140$ & F-value $=28.076$ & & \\
\hline & Adjusted $\mathrm{R}^{2}=\mathbf{0 . 1 3 5}$ & Sig $=\mathbf{0 . 0 0 0}$ & & \\
\hline & Campaign 3 & Standardized beta & t-value & Sig \\
\hline \multirow[t]{8}{*}{$\mathrm{a}$} & Dependent variable: $\mathbf{C C}$ identification & & & \\
\hline & Constant & & 14.351 & 0.000 \\
\hline & Positive WOM & 0.164 & 3.881 & 0.000 \\
\hline & Negative WOM & -0.176 & -4.230 & 0.000 \\
\hline & Social Value & 0.218 & 5.195 & 0.000 \\
\hline & $\mathrm{R}^{2}=0.124$ & F-value $=24.241$ & & \\
\hline & Adjusted $\mathrm{R}^{2}=\mathbf{0 . 1 1 9}$ & Sig $=\mathbf{0 . 0 0 0}$ & & \\
\hline & Campaign 4 & Standardized beta & t-value & Sig \\
\hline \multirow[t]{7}{*}{$\mathrm{a}$} & Dependent variable: $\mathbf{C C}$ identification & & & \\
\hline & Constant & & 14.809 & 0.000 \\
\hline & Positive WOM & 0.083 & 2.012 & 0.045 \\
\hline & Negative WOM & -0.212 & -5.146 & 0.000 \\
\hline & Social Value & 0.263 & 6.317 & 0.000 \\
\hline & $\mathrm{R}^{2}=0.138$ & F-value $=27.448$ & & \\
\hline & Adjusted $\mathrm{R}^{2}=\mathbf{0 . 1 3 3}$ & Sig $=\mathbf{0 . 0 0 0}$ & & \\
\hline
\end{tabular}

